\title{
CONCEPTUAL FOUNDATIONS OF COMPANY CASH FLOW PLANNING
}

\section{Galyna Drebit}

State University "Kyiv National Economic University"

\section{(C) MESTE NGO}

JEL Category: G32, 021

\begin{abstract}
The article deals with the conceptual foundations and principles of cash flow planning that will enable coherence between cash flow and tactical and strategic objectives of the company. An important objective of this is monitoring the formation and use of payment instruments as well as providing financial resources for the operating, financial performance and an investment either. The author analyzes the methods of cash flow planning (economic - statistical, economic - mathematical, technical - economic), its principles (complying the proportions of funds distribution and their minimum required volume, flexibility, evaluating the effectiveness of funds usage, adequate spacing and planning methods) as well as external and internal factors that influence the effectiveness of planning. Much attention is paid to different kinds of cash flow planning: strategic, current, operational and the making of the payment calendar and tasks which it solves. The structure of the cash flow budget has been surveyed. The causes of deficiency and excess cash and ways to balance them have been analyzed: attracting of additional loan capital, reducing of costs, improving the work with current assets, reducing of investment program, and early repayment of long-term loans. Two basic methods (alignment and synchronization), used in the process of the cash flow optimization, have been mentioned. Much attention is paid to the stages of the cash flow planning implementation process. They are: planning without automation, automated planning and formalized planning. So the analyzed aspects will allow achieving a systematic approach in cash flow planning, in coordination of their movements and tasks of the enterprises.
\end{abstract}

Keywords: cash flow, operating, investing and financing activities, accumulation, income, finance resources, strategic, current, operational planning, planning principles, stages of planning.

\section{INTRODUCTION}

In the modern business environment the cash flow planning of the company is an essential part of financial planning. In countries with developed market economies the role of business financial planning is constantly growing. However, current

Address of the author:

Galyna Drebit

埄”' galyna-drebit@i.ua methods of planning and financial management can not be used effectively yet. In many domestic companies cash flow planning is limited only to the calculation of cash sources and outflows, it means to current planning. Cash flow planning is often reviewed in developing budget funds in the scheduled period, taking into consideration only the basic components of the flow.

In recent years, cash flow planning is becoming increasingly important in the works of foreign and Ukrainian scientists. 
Such investigators as L. Bernstein (1996) and B. Kollas (1997) consider planning cash flows only in the short term, Van Horn (1996) defines cash flows forecasting as an opportunity to determine the time and the amount of the income and expenditure of funds, A. Poukok, and A. Taylor (1996) consider cash flows planning a part of the development of a plan for working capital.

R. Ackoff (2002) uses the term "plans' integration" in the narrow sense, D. Han (1997) uses the term "integrated system of reduced planning" that comes to complex of periodic and non-periodic plans.

The Ukrainian scholars O. Orlov (2002) and M. Gorohov (1998) admit only short-term planning. According to A. Poddieriogina cash flow planning makes it possible to identify the sources of capital and identify its use in a subsequent period. (Podderogin, Buriak, \& Kalach, 2001)

The Ukrainian economist I. Blank believes that cash flow planning is a development process of a system of plans to the formation of different types of flows in the financial and operating activities in the next period. (Blank I., 2002)

P. Krush, S. Polischuk, and A. Filimonov (2012), and V. Stepura (2012) examine the relationship of strategic planning and budget planning, their coordination in an integrated system of budget planning.

Determining the significant contribution of scientists in this field it should be noted that some issues of financial planning of enterprise activity are still in need for further investigation. In particular, it concerns such issues as defining the role and functions of cash flow planning in ensuring the financial stability of enterprises, methodological support of the financial planning and its integration, the development of the conceptual foundations of planning.

The purpose of this study is to reveal the theoretical and methodological positions as for the formation of financial cash flows planning system and the analysis of a wide range of methods and techniques of planning to ensure enterprise financial stability.

Focus on sustainable development shows the necessity in changing a paradigm in financial planning in Ukraine on the basis of the synthesis of national practice and achievements of international experience.

\section{BASIC METHODS AND PRINCIPLES OF THE CASH FLOW PLANNING}

Industry cash flow planning is one of the most important areas of financial activity, which aims to efficiently synchronize existing cash flows for the financial equilibrium of the company. Indeed, in modern terms, there is a lack of funds to implement the operational and financial activity, the risk of losing solvency and asynchronism of revenues and expenses.

Based on the material described above, the main objectives of cash flow planning are: efficient use of funds; control over the formation and use of payment instruments; providing investment, operating and financing activities with necessary financial resources; equalizing payments in order to avoid excessive fluctuations in cash flow.

Cash flow planning helps company management ensure proper business financing or withdrawal of money from circulation. Such financing can be achieved through negotiation with contractors to make faster payment, with banks to organize short-term loans, with suppliers to delay payment. Removing money from circulation can be done in the following ways: deposits in banks in order to obtain interest, granting deferrals to contractors to improve partnerships, funds withdrawal from the company in order to invest in securities, increase of production.

Cash flows also can be simply accumulated to create a "cushion", which is especially important at the stage of financial planning in the company where plans differ significantly from the actual situation.

When planning cash flow, in addition to deciding about budget as a whole, it is important to calculate another aspect. The flow from operating activities should be positive. In this part of the budget the company earns its own profit. In a monthly production capacity the company has to accumulate its profit. The flow from investing activities should be negative, i.e. the company should invest its money in the purchase of new equipment. The flow from financing activities balances the other two activities. 
If the enterprise flow from operating activities is negative and the flow from investing activities is positive, it is a warning sign, since the company is funding the current activities by selling assets. It must be clear, that such a company cannot expect to succeed in the future.

Thus, cash flow planning allows the company to move into the foreground. It can be added that the plan of income and expenses will not show such overview as budget of cash flow, because investment in fixed assets are not expenses, so that they do not reduce taxable income. And if the budget is made only of income and expenses, the acquisitions of fixed assets will not be seen at all (if the process has been built correctly in terms of accounting).

In cash flow planning a system of methods is used that allows achieving the required results. These include methods of economic - statistical, economic - mathematical, technical - economic calculations, comparison, balance, etc.

Besides these methods there is also a system of cash flow planning principles. The main principles are the following: the principle of the proportions of cash flow distribution between the main components of the production process; the principle of flexibility of cash flow planning, adequate spacing and planning methods; the principle of evaluating the effectiveness of funds usage and justification of the minimum required amount of money that should be in company circulation to provide its liquidity.

The choice of techniques and methods for cash flow planning depends on a number of external and internal factors. External factors that influence the effectiveness of cash flow planning can include the conditions of enterprise management, forming product prices and government support. The most important internal factors are: the subject of work and the main company resource; significant variability of factors of the internal environment and the need of making decisions under significant uncertainty of these factors; the main operational activities of the company; economic results of the company (losses, the lack of funds, etc.).

The current system of cash flow planning principles allows simplifying the task and improves the accuracy of forecasts. The main principles among them are:

- the principle of justification of a minimum required amount of money that should be in circulation of a company to provide its liquidity. This principle has to determine the minimum amount of money required for the continuation of company operations and timely choice of methods of financing. Without reliable methods of evaluating financial needs the company may be left without sufficient funds to pay interest on the loan, payments to providers, for rent, utilities and more. An enterprise could face bankruptcy if it is unable to pay its contractual obligations, such as interest on the loan;

- the principle of the proportions of funds distribution between the main components of the production process. This principle is determining the amount of funds for the maintenance of fixed and working capital. It is important to know not only the value of the expected revenue, but also its distribution in the industrial and economic activities of a company, because it affects the maintenance of solvency of a company and reputation in the business environment;

- the principle of flexibility of cash flow planning. This principle is the sort of analytical reference, which should specify the required amount of receipts to balance them with the planned costs. That this should be corrected promptly in the case of reserve or deficit formation, i.e. when changing internal and external conditions of the company. By this principle one of the important tasks of planning cash flow must be solved - the equalization of payments in order to avoid excessive fluctuations of cash flow;

- the principle of evaluating the effectiveness of cash use. The fundamental relationship of cash flow to reproductive processes occurring in the company determines the methods of evaluating cash flows in the process of their planning according to various criteria. In terms of ensuring adequate solvency from one side, and the required level of profitability on the other, the analysis of cash flows in the process of their planning is a necessary phenomenon that allows an overall evaluation mechanism 
of cash flow planning of an industrial company;

- the principle of intervals (spacing) and planning methods adequacy. It's necessary to admit that the choice of cash flow planning justification method should take into account the time measurement of planning that promotes adequate methods and maturity of the plan and, therefore, increases the accuracy of forecasting calculations. (Igonina, 2004)

\section{TYPES OF PLANNING AND ITS MAIN STAGES, THE MAIN FEATURES OF THE PAYMENT CALENDAR ADJUSTMENT}

Cash flows of the company should be planned as for the current period and also for the medium and long term periods, because for all production processes substantial cash investments throughout the period of the functioning of company are required. According to this, there are several types of cash flow planning for businesses: strategic (long-term) planning (1-3 years), current (mid-term) planning (up to 1 year) operative (short-term) planning (month, quarter). Each type of cash flow planning of company is a part of a comprehensive plan for the development of a company and has certain characteristics of planning process organization. Thus, the strategic planning is a tool that will facilitate management decisions regarding cash flow. In its terms the policy of a company cash flow formation will be developed. As a part of a current planning the revenues and expenses of funds planning, forecasting the balance of cash and forecasting of income will be implemented. Within the operational planning integrated budgets of funds that should contain elements that reflect the scope, purpose and period of the individual payments will be developed. So here it is also necessary to develop a short-term plan for shorter periods (month, decade) in the form of payment calendar.

Payment calendar is a plan of production financial activities organization, in which all sources of cash revenues and expenses for a specific period of time are interconnected (by the calendar). It completely covers the circulation of money of the company, makes it possible to link the cash revenues and payments in cash and noncash, and ensures permanent solvency and liquidity.

The payment calendar is being drawn up by the financial service of the company. The targets of the cash flow budget are divided by month and smaller periods. The terms are determined on the basis of the frequency of major payments of the company.

In the process of the payment calendar establishment the following objectives are decided:

1. The organization of temporary docking of revenues and future company expenses accounting;

2. The daily record of changes in the information base;

3. The calculation of the need for short-term financing;

4. Analysis of the financial market searching for the most reliable and profitable place for temporary free funds allocation;

5. Analysis of defaults and organization of measures to eliminate their causes.

The payment calendar is based on the actual information base of cash flow, which includes: contracts with contractors; accounts to pay for the product; bank documents of revenues; schedules of wages; status of payments to debtors and creditors; law on time payments on financial obligations to the budget and extrabudgetary funds.

For the effective establishment of a payment calendar the financial manager needs to control information about balances in bank accounts, expenses, average balances for the day, the state of marketable securities of the company, planned revenues and payments planned for the future.

The structure of the cash flow budget (CFB) is similar to the structure of the report of cash flows in the company. However, it is not a regulated but management form, so it has some differences.

The CFB consists of three major parts: operating, investing and financing activities.

Operating activities include the production of goods and services and their implementation. Revenues and expenses exist in operating activities. 
Investing activities include long-term investments and revenues from the purchase of fixed assets and other investments. This part of the plan is strategically important because without the investment development there will be no company.

Financing activities are the most important part for "combining" the whole budget. Planning of operating activities is ensured by a number of separate departments of a company. Investing activities are planned by management and production units. Financing activity is planned by an accounting company and the financial department. But after the calculation and checking of data it can happen that the cash flow from current activities will be unfavorable. This does not mean that it is negative. In CFB there are two lines: cash balance at the beginning and the end of the period. Therefore, in case of having extra money owners may decide to prepayment of the credit or investing in fixed assets. In case of having a shortage (negative balance at the end of the month) owners may seek additional funding.

Typically, this budget is made for a year being divided into quarters and months. Budgeting is usually done by managers or owners, as it's their task to determine the strategic priorities of the company. In addition, the preparation of the CFB for a year is not as informative as for a shorter period, as this budget is not meant for company performance but to provide its financing. Therefore, we consider only the process of budgeting for a short period of time (month or quarter).

The process of cash flow planning per month consists of several stages:

- Stage I deals with a prognosis for the current month. It's usually conducted on the 20-25th day of the month. At this stage specifying data from departments is collected to determine the balance of cash on hand and in accounts at the end of the month. This amount of the cash flow budget for the next month will be a balance at the beginning.

- Stage II means gathering of information from all the departments about expenses and revenues in a planned month. Planned revenues and expenses must be generated being divided for weeks, sometimes even days. This is done in order to avoid cash gaps not only at the end of the month but also for the entire period. Typically, this method of planning helps unstable companies which only began to use financial and economic planning.

- Stage III means the calculation and checking of the cash flow budget. The economics and planning department deals with this process. It is important that in a common information system there was general CFB and the application of all departments till the next stage. For each item of expenses their codes can be determined (they can be unique).

- Stage IV foresees the discussion of the cash flow budget in the budget committee. Small businesses may not have the budget committee, and then there is a discussion among all the participants of the cash flow budget establishment and the management of the company. At this meeting the economics and planning department presents a cash flow budget broken down into days or weeks. Upon request each cost item can be detailed. This is achieved through the use of software.

Let's us review how the control of cash flow is being carried out. If such a plan has been made, all money orders must be signed by the head of the economics and planning department, because this department should monitor the payment within the plan. Once the economics and planning department notes excess payment or non-receipt of revenue (credit), it sends a signal to the finance manager for a decision or search who is guilty. This can be a sales department, a production department or an accounting department, which calculated taxes incorrectly. When the company planning system is perfectly arranged, a reduction of bonuses due to incorrect calculation may be applied and for compliance with the plan the workers receive an additional bonus.

The result of the development of a cash flow plan can be manifested both either in a deficit or surplus of cash flows. Therefore, at the final stage of cash flow management they both are optimized by balancing volume and time, synchronizing their formation in time and optimizing the cash balance on the current account.

Both deficit and excess of cash flow have a negative impact on the company. The negative effects of deficit of cash flow can be manifested in 
the reduction of company liquidity and solvency, in the increase of overdue payables to suppliers of raw materials, in the increase of the share of overdue loans after the received financial credits, in wage arrears, in the increase of the financial cycle duration and ultimately in the profitability decrease of company's equity and assets use.

The negative effects of excess cash flow can be manifested in the loss of real value of temporarily unused funds against inflation, loss of potential income from the unused portion of funds in shortterm investments of the latter, which ultimately also affects the level of return on assets and equity.

The majority of financiers consider that the amount of cash flow deficit can be balanced by:

1. raising additional long-term debt or own capital;

2. depriving of non-core fixed assets;

3. costs shortage;

4. improving the work with current assets;

5. reducing the investment program of the company

The amount of excess cash flow must be balanced by:

1. the increase in investment activity of the company;

2. the prepayment of long-term loans;

3. the expansion or diversification of activities.

In the process of optimizing of cash flow over time two basic methods are used: alignment and synchronization. The alignment of cash flows aims at smoothing their volumes in individual intervals of the reporting period. This optimization method eliminates some extent seasonal and cyclical variations in the formation of cash flows (both positive and negative), optimizing parallel average balances and increasing liquidity. The results of this optimization method of cash flows over time are measured using standard deviation or coefficient of variation, which should decrease in the process of optimization.

The synchronization of cash flows is based on the convariation of their positive and negative types.

During synchronization there must be ensured the increase in the correlation between these two types of cash flows.
By integrating operating, current and strategic cash flow planning in a single process the consistency of cash flows with the tactical and strategic objectives of a company in time and space can be achieved. This approach to cash flow planning concepts is also aimed at ensuring constant financial balance; at achieving of liquidity and solvency; at maintaining the appropriate level of business activity.

The process of cash flow planning implementation includes the following steps:

Step 1 - planning without automation. At this stage of planning departments give their notes with data, the economics and planning department introduces them into one system and prints them for managers. The duration of this phase is the greatest, because in the process of its implementation the following is defined: what types of plans have to be made, who is responsible for what, what terms should be possible. Typically, this phase lasts about three to four months, depending on the size of the company and the interest of the chief manager and departments in implementing the planning.

At this stage there are various consultations between the chief manager, the chief accountant and the head of the economics and planning department. The chief manager wants to understand how effectively the company works, what income or loss there is, how much money they have and who has the debts.

Step 2 - automated planning. At this stage an information system for collecting data from departments and their consolidation is created. Through the informatization service of the company the process of drawing up plans is being automated.

At the stage of automation there is also the need to provide connectivity between budgets. Major units of the cash flow budget should intermingle with two other budgets, for example, the account balances and cash register in the budget for the balance sheet balances must be equal to the cash flow budget. 
Step 3 - formalized planning. At this stage planning regulations are being developed including the following: departments involved in planning; terms of information preparation; various options for development; process of drafting and approving plans; responsibility for plan implementation.

The implementation of the cash flow planning usually needs about six months. An extremely important factor is the determination of a chief manager. Its success depends entirely on how he is interested in implementing this planning. Sometimes, production departments are not willing to plan, they might feel that it is time consuming and is not appropriate. In this case, the position of a chief manager is crucial.

\section{CONCLUSIONS}

Consequently, the cash flow planning of a company is based on a system approach that combines the goals, objectives, methods and principles of planning with the types of plans that specifies and complements each other covering all aspects of the business. Due to the need to adapt the system of financial planning to changeable business environments there is a need to build a system of integrated financial planning.

Integration of financial planning allows to minimize administrative costs and consider the risk factors in the process of making plan decisions to ensure the financial stability of enterprises. The introduction of a conceptual approach to financial planning system will facilitate more effective cash flow planning through planning decisions adjustments depending on the level of financial stability of enterprises.

\section{WORKS CITED}

Ackoff, R. (2002). Ackoff about management. SP.: Peter.

Bernstain, L. (1996). Financial Statement Analysis: Theory, Practice and Interpretation. Moscow: Finance and Statistics.

Blank, I. (2002). Cash flow management. Kyiv: Nika - Center, Elga.

Gorohov, M., \& Maleev, V. (1998). Business - planning and investment analysis. Moscow: Information Publishing House "Filin".

Han, D. (1997). Planning and control: the concept of controlling. Moscow: Finance and Statistics.

Igonina, K. (2004) Theoretical aspects of cash flow planning. Finance and Credit (5), 17-21.

Kollas B. (1997). Financial management of the enterprise. Problems, concepts and methods: A Tutorial. Moscow: Finance, Unity.

Krush P.V., Polischuk, S.V., \& Filimonov, A.G. (2012). The integrated system of budget planning. Innovative Economy (10).

Martzyn, V. S. (2008). Planning as a basic component of financing activities. Finance of Ukraine (4).

Moiseeva, O. (2012). Planning and optimization of cash flows in the company. The financial market of Ukraine, (7-8).

Orlov, O. (2002). Planning of Industrial Enterprise. Kyiv: Skarby.

Podderogin, A., Buriak, L., Kalach, N. (2001). Financial management. Kyiv: KNEU.

Poukok, A., \& Teylor, A. (1996). Financial Planning and Control. Moscow: Infa.

Stepura, V.V. (2012). Conceptual bases of integrated financial planning. Scientific Bulletin (3). Kyiv: Finance, banks, investment.

Van Horn, G. (1996). Fundamentals of Financial Management. Moscow: Finance and Statistics.

Veselovskyi, O. (2011). Cash flow planning. The financial market of Ukraine (10). 
Received for publication: $\quad 27.01 .2015$

Revision received: $\quad 10.02 .2015$

Accepted for publication: $\quad 02.03 .2015$

\section{How to cite this article?}

Style - APA Sixth Edition:

Drebit, G. (2015, July 15). Conceptual foundations of company cash flow planning. (Z. Čekerevac, Ed.) MEST Journal, 3(2), 31-38. doi:10.12709/mest.03.03.02.03

Style - Chicago Sixteenth Edition:

Drebit, Galyna. 2015. "Conceptual foundations of company cash flow planning." Edited by Zoran Čekerevac. MEST Journal (MEST) 3 (2): 31-38. doi:10.12709/mest.03.03.02.03.

Style - GOST Name Sort:

Drebit Galyna Conceptual foundations of company cash flow planning [Journal] // MEST Journal / ed. Čekerevac Zoran. - Belgrade : MEST, July 15, 2015. - 2 : Vol. 3. - pp. 31-38.

Style - Harvard Anglia:

Drebit, G., 2015. Conceptual foundations of company cash flow planning. MEST Journal, 15 July, 3(2), pp. 31-38.

Style - ISO 690 Numerical Reference:

Conceptual foundations of company cash flow planning. Drebit, Galyna. [ed.] Zoran Čekerevac. 2, Belgrade : MEST, July 15, 2015, MEST Journal, Vol. 3, pp. 31-38. 